\title{
SOCIODEMOGRAPHIC AND EPIDEMIOLOGICAL PROFILE OF WOMEN USERS OF A PSYCHOSOCIAL ATTENTION CENTER
}

\author{
Perfil sociodemográfico e epidemiológico das mulheres usuárias de um \\ centro de atenção psicossocial
}

\section{Perfil sociodemográfico y epidemiológico de las mujeres usuarias de un centro de atención psicosocial}

Juliane da Silva Pereira ${ }^{1}$, Mércia Alcântara Feitosa Valença², Valquiria Farias Bezerra Barbosa ${ }^{3}$, Ana Carla Silva Alexandre ${ }^{4}$, Silvana Cavalcanti dos Santos ${ }^{5}$, Rebeca Cavalcanti Leal ${ }^{6}$

\section{How to cite this article:}

Pereira JS, Valença MAF, Barbosa VFB, Alexandre ACS, Santos SC, Leal RC. Sociodemographic and epidemiological profile of women users of a psychosocial attention center. $2020 \mathrm{jan} / \mathrm{dez} ; 12: 833-839$. DOI: http:// dx.doi.org/0.9789/2175-5361.rpcfo.v12.7813.

\footnotetext{
ABSTRACT

Objective: This study aimed to analyze the sociodemographic and epidemiological profile of women with mental disorders, emphasizing the gynecological, reproductive and sexual aspects. Method: A cross-sectional study, carried out at the Psychosocial Attention Center, with 31 women, aged 18 years or more, undergoing regular treatment. A data collection instrument in a structured format was used and data were analyzed using the SPSS software, version 18.0. This project was approved by one Research Ethics Committee under registration CAAE 56546216.0.0000.5195. Results: There was a predominance of women in drug therapy (96.8\%), low sexual activity (61.3\%), high adherence to cervical cancer screening test (74.2\%) and low adherence to family planning (77.4\%). Conclusion: An integral care provided to women with mental disorders, users of the Psychosocial Attention Care, requires an alignment among the policies of integral attention to women's health and mental health, through matrix support with primary health care.

Descriptors: Delivery of health care, Nursing care, Deisntitutionalization, Women `s health, Mental Health.

\section{RESUMO}

Objetivo: Analisar o perfil sociodemográfico e epidemiológico das mulheres com transtornos mentais, com ênfase aos aspectos ginecológicos, reprodutivos e sexuais. Método: Estudo transversal, realizado no Centro de Atenção Psicossocial, com 31 mulheres, com

1 Nursing Graduate by the IFPE, MSc student in Health Management and Economics by the UFPE.

2 Nursing Graduate by the IFPE, Specialist's Degree in Occupational Nursing by the Instituto Brasileiro de Formação (IBF), Registered Nurse working at UNIMED Pleno Caruaru.

3 Nursing Graduate by the UFPE, PhD in Human Sciences by the Universidade Federal de Santa Catarina (UFSC), Head of the Research Group named Health Care and Provision at IFPE, Professor at IFPE.

4 Nursing Graduate by the Autarquia de Ensino Superior de Arcoverde (AESA/ESSA), PhD in Health Sciences by the Instituto Universitário Italiano de Rosário (IUNIR), Professor at IFPE.

5 Nursing Graduate by the Universidade Estadual da Paraíba (UEPB), MSc in Public Health by the Fundação Oswaldo Cruz (FIOCRUZ), Professor at IFPE.

6 Nursing Graduate by the IFPE, Residency student in General Emergency at Hospital Regional do Agreste (HRA).
} 
idade igual ou superior a 18 anos e em tratamento regular. Utilizou-se instrumento de coleta estruturado, os dados foram analisados no SPSS versão 18.0. Esse protocolo foi aprovado por Comitê de Ética em Pesquisa sob o CAAE 56546216.0.0000.5195. Resultados: Houve predominância de mulheres em terapia medicamentosa $(96,8 \%)$, baixa atividade sexua (61,3\%), alta adesão ao exame preventivo de câncer de colo do útero (74,2\%) e baixa adesão ao planejamento familiar (77,4\%). Conclusão: Para a integralidade do cuidado prestado às mulheres com transtorno mental, usuárias do Centro de Atenção Psicossocial, é necessário um alinhamento entre as políticas de atenção integral a saúde da mulher e saúde mental, via apoio matricial com a atenção primária de saúde.

Descritores: Assistência à saúde, Cuidados de enfermagem, Desinstitucionalização, Saúde da mulher, Saúde mental.

\section{RESUMÉN}

Objetivo: Analizar el perfil sociodemográfico y epidemiológico de las mujeres con trastornos mentales, con énfasis en los aspectos ginecológicos, reproductivos y sexuales. Método: Estudio transversal, realizado en el Centro de Atención Psicosocial, con 31 mujeres, con edad igual o superior a 18 años y en tratamiento regular. Se utilizó instrumento de recolección estructurado, los datos fueron analizados en el SPSS versión 18.0. Esta investigación fue aprobada en el Comité de Ética bajo el CAAE 56546216.0.00.00.5195. Resultados: Hubo predominio de mujeres en terapia medicamentosa $(96,8 \%)$, baja actividad sexual $(61,3 \%)$, alta adhesión al examen preventivo de cáncer de cuello de útero $(74,2 \%)$ y baja adhesión a la planificación familiar (74,2\%) 77,4\%). Conclusión: Para la integralidad del cuidado prestado a las mujeres con trastorno mental usuarias del Centro de Atención Psicosocial es necesario un alineamiento entre las políticas de atención integral a la salud de la mujer y de salud mental, a través del apoyo matricial con la atención primaria de salud.

Descriptores: Prestación de atención de salud, Atención de enfermaria, Desinstitucionalización, Salud de la mujer, Salud mental.

\section{INTRODUCTION}

In 2004, while pursuing improvements in care for women, the Brazilian Ministry of Health presented the National Policy for Women's Health Comprehensive Care. ${ }^{1}$ This policy incorporates, in a gender approach, integrality and health promotion as guiding principles and seeks to consolidate advances in the field of sexual and reproductive rights. ${ }^{1}$ It also includes combined prevention, in other words, the shared prophylaxis and treatment of Sexually Transmitted Infections (STIs), chronic non-communicable diseases and cancer, especially Breast Cancer (BC) and Cervical Cancer (CC). ${ }^{2}$

The female public is highly vulnerable to mental illness, such as the prevalence of common mental disorder, which ranges from $28.7 \%$ to $50 \%$, among females and the elderly. ${ }^{3}$ So, women, including those who are cared for in Centros de Atenção Psicossocial (CAPS) [Psychosocial Care Centers], they need a comprehensive look at their health. ${ }^{4}$

Depression accounts for $4.3 \%$ of the global disease burden and is the leading cause of disability worldwide, representing $11 \%$ of all years experienced with disability globally, mainly by women. Due to stigmatization and discrimination, people with mental illness have their human rights violated, in addition to economic losses, social and cultural rights, with restrictions on the rights to work, education, reproductive rights and the best standards of health care. ${ }^{5}$

Care for mental health and women's health are fragmented in the different health facilities, compromising their comprehensiveness. ${ }^{6}$ Pointing to the need to know the profile of users to invest in matrix support practices that integrate all levels of health care, but mainly, the CAPS teams and those of the Family Health Strategy (FHS).

As suggested by the Ministry of Health, through the National Mental Health Policy (NMHP), mental health actions in Primary Health Care (PHC), must transcend the traditional, biologic and medicalizing model, and invest in health promotion, considering the uniqueness of people and their protagonism. ${ }^{7}$

The health of women bearing Mental Disorders (MD) is a topic little discussed in the scientific literature, reflecting the fragmentation of women's health care, the invisibility of their singularities, and the suppression of their rights. ${ }^{8}$ Hence, this study aims to analyze the profile sociodemographic and epidemiological aspects of women attending a CAPS, emphasizing their gynecological, reproductive, and sexual aspects.

\section{METHODS}

It is a cross-sectional study with a quantitative approach, which was performed at CAPS II in the Pesqueira city, Pernambuco State, with the favorable legal opinion from the Research Ethics Committee of the Hemotherapy Foundation of Pernambuco, under the Certificado de Apresentação para Apreciação Ética (CAAE) [Certificate of Presentation for Ethical Appreciation] No. 56546216.0.0000.5195.

The sample was selected by sampling by criteria. Inclusion criteria were, as follows: being female, being 18 years old or older, being under intensive or semi-intensive regular psychosocial monitoring during the research period. The three types of service provided by mental health services are: intensive treatment (daily attendance at the service), semi-intensive (frequency on alternate days) and non-intensive (frequency every two weeks or monthly in a context of discharge planning). ${ }^{9}$

Exclusion criteria were as follows: not being present during the data collection period and being in acute mental distress that would impair their free decision to participate of this research. The final sample consisted of 31 women who made up $100 \%$ of the women population undergoing regular and continuous treatment.

Data collection took place through the application of a structured questionnaire, from Monday to Friday, in the morning shift, from March to July 2017, in a nursing office and individually to ensure the autonomy and privacy of the participants. There was no interference with the CAPS routine. The instrument was pre-tested and consisted of sociodemographic variables and related to mental and women's health.

Data were stored and analyzed by the Statistical Package for the Social Sciences-SPSS, version 18.0. The Chi-Square Test $(\chi 2)$ was used to find the association between statistically 
significant variables, considering the significance level of $95 \%$, in which $a \leq 0.05$.

\section{RESULTS}

Table 1 addresses the sociodemographic data of the women in the CAPS. The average age was 42.48 years old, with a minimum age of 19 years old and a maximum of 67 years old. There was a predominance of $22(70.4 \%)$ women of childbearing age. ${ }^{10}$ Regarding the race, brown skin color predominated, represented by 19 women $(61.3 \%)$. In regard to the marital status, $15(48.4 \%)$ were single; as for education, it is observed that none has a college degree, while only 3 (9.7\%) completed high school.

Table 1 - Sociodemographic profile of women assisted at the CAPS, Pesqueira city, Pernambuco State, 2017.

\begin{tabular}{|c|c|c|c|c|c|}
\hline Variable & Avg. $^{a}$ & $X(S D)^{b}$ & $\begin{array}{l}\text { Min- } \\
\text { Max }^{c}\end{array}$ & (N) & (\%) \\
\hline Age (full years) & 42.48 & 11.975 & 19 / 67 & 31 & 100 \\
\hline \multicolumn{6}{|l|}{ Race } \\
\hline Brown & & & & 19 & 61.3 \\
\hline White & & & & 7 & 22.6 \\
\hline Indian & & & & 3 & 9.7 \\
\hline Black & & & & 2 & 6.5 \\
\hline Total & & & & 31 & 100 \\
\hline
\end{tabular}

\begin{tabular}{lcc}
\hline Marital status & & \\
Single & 15 & 48.4 \\
Married & 9 & 29 \\
Divorced & 5 & 16.1 \\
Widow & 2 & 6.5 \\
Total & 31 & 100 \\
\hline
\end{tabular}

\begin{tabular}{lcc}
\hline Education & & \\
Incomplete & 13 & 41.9 \\
Elementary & & \\
School & & \\
Complete & 13 & 41.9 \\
Elementary & & \\
School & & \\
Complete High & 3 & 9.7 \\
School & & \\
Illiterate & 2 & 6.5 \\
College & 0 & 0 \\
Total & 31 & 100 \\
\hline
\end{tabular}

Superscript: a. Average b. Standard deviation c. Minimum - Maximum
Table 2 shows the characterization of sexual life, treatment, and self-reported diagnosis of the disease, in order to show the interference of this diagnosis in the affective and sexual lives. There were found 37 answers for self-reported diagnosis since more than one answer was given per woman. Only 1 woman $(3.2 \%)$ did not undergo pharmacological treatment, 9 (24.3\%) reported depression, and $11(35.5 \%)$ stated that their diagnosis has interference in sexual life.

Among the changes in sexual life, 8 women $(25.8 \%)$ feel an either absence or decreased libido and 9 (29\%) have an altered sexual function. Only 7 women $(22.6 \%)$ reported a satisfactory affective relationship with their partner and 19 women (61.3\%) do not have an active sex life. The altered sexual function is related to the presence of some discomfort during sexual intercourse that makes the sexual act impossible, such as dyspareunia and burning. As for the number of partners during the entire affective life, there is an average of 2.44 partners and the average age of the coitarche was 16.32 years old.

Table 2 - Characterization of drug therapy, self-reported diagnosis and sexual life of women assisted at the CAPS, Pesqueira city, Pernambuco State, 2017.

\begin{tabular}{lcc}
\hline \multicolumn{1}{c}{ Variable } & (N) & (\%) \\
\hline Pharmacological treatment & 30 & 96.8 \\
Yes & 1 & 3.2 \\
No & 31 & 100 \\
Total & & \\
\hline Self-reported diagnosis & 9 & 24.3 \\
Depression & 8 & 21.6 \\
Anxiety/Unrest & 7 & 18.9 \\
Mental disease & 4 & 10.8 \\
Unknown disease & 2 & 5.4 \\
Chronic disease & 2 & 5.4 \\
Different of everything & 2 & 5.4 \\
Aggressiveness & 2 & 5.4 \\
Complex disease & 1 & 2.7 \\
Shame & 37 & 100 \\
Total & & \\
\hline
\end{tabular}




\begin{tabular}{lcc}
\hline \multicolumn{1}{c}{ Variable } & (N) & (\%) \\
\hline Interference of the diagnosis in sex life & 11 & 35.5 \\
Yes & 20 & 64.5 \\
No & 31 & 100 \\
Total & & \\
\hline Interference of the diagnosis & 19 & 61.3 \\
Do not know/Not applicable & 8 & 25.8 \\
Absence or decreased libido & 2 & 6.4 \\
Abandon & 2 & 6.4 \\
Do not feel pleasure in having sex & 0 & 0 \\
Fear & 31 & 100 \\
\hline Total & &
\end{tabular}

\section{Active sex life}

\begin{tabular}{lll} 
No & 19 & 61.3 \\
Yes & 12 & 38.7 \\
Total & 31 & 100 \\
\hline
\end{tabular}

\begin{tabular}{lcc}
\hline Affective relationship with the partner & & \\
Do not know/Not applicable & 19 & 61.3 \\
Good & 7 & 22.6 \\
Regular & 3 & 9.7 \\
Bad & 2 & 6.4 \\
Total & 31 & 100 \\
\hline
\end{tabular}

\section{Sexual function}

$\begin{array}{lcc}\text { Unaltered } & 16 & 51.6 \\ \text { Altered } & 9 & 29 \\ \text { Do not know/Not applicable } & 4 & 12.9 \\ \text { Inexistent } & 2 & 6.5 \\ \text { Total } & 31 & 100\end{array}$

Concerning the reproductive health, it was observed that 20 women $(64.5 \%)$ have children, with an average of 4.35 pregnancies, 3.40 births, and 1.86 abortions. With regard to family planning, only 7 (22.6\%) used any contraceptive method, 4 (12.8\%) underwent a surgery to occlude the Fallopian tubes, $1(3.2 \%)$ using the male condom, 1 (3.2\%) used oral contraceptives and 1 (3.2\%) used injectable contraceptives. Observing the health care during pregnancy, 18 (58.1\%) had prenatal consultations, with an average of 6.46 consultations, and $8(25.8 \%)$ had some complications during the pregnancy period.

Women's health was characterized by the Cervical Cancer Screening Test (CCST) being performed in variable moments, place and time interval between the performance of the CCST, clinical examination, Breast Self-Examination (BSE), and breast image exams, as well as STI prevention. Considering the total of 31 women, 23
(74.2\%) had undergone the CCST. Of these, $21(67.7 \%)$ performed at a PHC unit; $16(51.6 \%)$ did it less than a year ago, $4(12.9 \%)$ did it between one and two years, 2 (6.5\%) did it more than two years ago and 9 (29\%) did not know how to answer or they didn't. Regarding the breast exam, $13(51.6 \%)$ have already undergone some breast exam; $5(16.1 \%)$ underwent a breast exam less than 1 year ago, 4 (12.9\%) between one and two years, and 4 (12.9\%) more than two years ago. Among them, 4 (12.9\%) underwent BSE, 5 (16.1\%) underwent mammography, 4 (12.9\%) underwent breast ultrasound and there was no report of clinical breast examination. Concerning the prevention of STIs, $22(71 \%)$ did not use preventive methods and 7 (22.6\%) used the male condom as a preventive method.

Table 3 provides data on the associations between the type of self-reported disorder, the use of psychotropic drugs, and the users' sexual activity.

Table 3 - Association between type of disorder and use of psychotropic drugs with sexual activity of women assisted at the CAPS, Pesqueira city, Pernambuco State, 2017.

\begin{tabular}{lccc}
\hline \multicolumn{1}{c}{ Variable } & \multicolumn{2}{c}{ Active sex life } & $\%$ \\
\hline Depression & Yes & No & \\
Yes & 3 & 6 & \\
No & 7 & 13 & 0.599 \\
Do not know & 0 & 2 & \\
Total & 9 & 20 & \\
\hline Anxiety & Yes & No & \\
Yes & 1 & 7 & \\
No & 9 & 12 & 0.177 \\
Do not know & 0 & 2 & \\
Total & 8 & 21 & \\
\hline Use of psychotropic & Yes & No & \\
drugs & 15 & 15 & \\
Yes & 0 & 1 & 0.325 \\
No & 15 & 16 & \\
Total & &
\end{tabular}

It was observed that there was no statistically significant association among all variables.

\section{DISCUSSION}

Analysis of sociodemographic data indicates the vulnerability of women according to their strata. When relating the age group to the presence of $\mathrm{MD}$, there is a prevalence among women of childbearing age and economically active, within the age group from 15 to 44 years old $(64.55 \%)$. This age profile is justified by the association of vulnerability factors for the development of MD such as socioeconomic difficulties, pre-existing comorbidities, social isolation, among others. ${ }^{12}$ Furthermore, the development of 
the first symptoms of severe MDs treated at CAPS occurs when the individual is still a young adult. ${ }^{4,11}$

Marital status has an impact on mental health, as being single has been an important risk factor, especially for depression. ${ }^{12}$ Low education is a factor of non-adherence to preventive exams, related to reduced access to information, which has a negative impact on self-care, understanding information and adopting preventive attitudes. ${ }^{13}$

As for pharmacological treatment, a high number of women who use pharmacological therapy persists, corroborating with other studies that point to the persistence of asylum practices, introducing medication overload to treat psychological suffering. ${ }^{8,14}$

The risky sexual behavior, as well as having multiple partners during life and the precocity of the coitarche are risk factors for CC and STIs. ${ }^{15}$ Therefore, CC screening should be performed in all women from 25 to 64 years old who initiated sexual activity and, every three years, if the first two annual exams are normal. ${ }^{16}$

Studies describe that women with MD, for the most part, have at least one child. ${ }^{8,17}$ Supported by this data, it can be addressed that despite the difficulties to play the role of mother, women bearing MD point to motherhood as an event that adds quality to their lives. ${ }^{6}$

Bearing in mind that MD can compromise autonomy, individualized care in family planning in PHC is essential, recognizing the reproductive right of these women and allowing them to decide whether they want to have children or not. ${ }^{6,18}$

As psychological distress in the perinatal period can enhance non-adherence to prenatal care, making mothers prone to obstetric complications, and can also impair child growth and development and contribute to predisposition to MD in children. ${ }^{15,19}$ Hence, multidisciplinary monitoring, systematic and continuous to women with MD in PHC, must obey the minimum number of 8 prenatal consultations, with interim monitoring between doctor and nurse. ${ }^{20}$ A joint effort to reduce perinatal mortality and improve the experience of attending women. ${ }^{21}$

CC corresponds to approximately $10 \%$ of malignant neoplasms diagnosed in the female population, being the second cause of death in women, surpassed only by BC. ${ }^{22,23}$ To reduce female morbidity and mortality, it is necessary to encourage adherence to preventive exams. In women bearing MD the average adherence to CCST varied, in different studies, between $23 \%$ to $69 \%$. $^{10,24}$

Herein, 26\% of women with MD had not undergone CCST. Among the factors that influence non-adherence to preventive exams, we can mention limited autonomy related to cognitive difficulties arising from MD; difficulty in accessing exams, or even, the unpreparedness of professionals to deal with these women. It should be noted that the stigma and denial of rights to these users are related to their double vulnerability: being a woman and having a MD. ${ }^{25}$

Given the $65 \%$ coverage for CCST, it is estimated that, in Brazil, between $12 \%$ and $20 \%$ of Brazilian women between 25 and 64 years old never underwent CCST. ${ }^{26}$ The main risk factors related to non-adherence to exams preventive measures were: being over 40 years old, having a low level of education and being single. ${ }^{27}$

Considering the aforesaid, the transversality of policies must provide care for women in the psychosocial care network, surpassing the model of homogenization of care provided to men and women. It is about ensuring care that embraces its singularities linked to gender issues. ${ }^{28}$

In Brazil, $\mathrm{BC}$ is the second most prevalent type in the female population. Although this type of cancer is diagnosed in the early stages, the Brazilian health network offers only $47 \%$ coverage for mammography, compromising early diagnosis and reducing the survival of diagnosed people, compared to developed countries (50\%-60\% against $85 \%){ }^{26,29}$

BSE is a useful tool for detecting BC, when associated with mammography and clinical examination. ${ }^{30}$ In this study, only $12.9 \%$ of women performed it.

Considering the prevention of STIs, adherence to preventive methods was observed by only $22.6 \%$ of women, in addition to the exclusive use of male condoms, which characterizes gaps in knowledge regarding available contraceptive methods. It appears that health education is a primary strategy to reduce barriers to access services and their strategies for protecting this population.

Herein, it was found that the variables of self-reported diagnosis and use of psychotropic drugs did not influence the sexual life of women, with no significance in the association between these variables. The experience of sexuality by women bearing MD did not suffer any interference from their health condition and/or the self-perception of their disease, although the sexuality of women with MD is treated as a controversial topic and is often related to the symptomatologic characteristics of the disorder.

Although the vast majority of respondents do not have an active sex life, it is important to recognize that sexuality is still present with representativeness similar to that of those without MD. Women with MD "have feelings, fall in love and love like anyone else, then wanting to express themselves sexually" 6:4 It follows from this fact that people with MD have conditions and rights to live their sexuality fully, although there is a significant path to be followed in the search for respect for their individuality and uniqueness and satisfactory health care..$^{8,24,25}$ It is therefore necessary to reestablish the right to femininity, enabling women to have a better quality of life and greater autonomy over their bodies. ${ }^{20}$

This study enabled the observance of the need for the empowerment of femininity, of being a woman with her singularities, on the part of women with $\mathrm{MD}$, given that they still face many difficulties for this full experience, with autonomy and freedom for the choices and actions that will influence their ways to live, your health and your completeness. Despite advances in the fields of health and access, they have partial and fragmented access to health, since they are still unable to experience their sexuality free from prejudice, stigma and access to all preventive methods against STIs and contraceptives, as well as not all 
the necessary information is available for them to make their decisions based on current health knowledge.

The limitations of this study are linked to the crosssectional design and the literary scarcity about the interface between women's health and mental health.

\section{CONCLUSION}

Bearing in mind the aforementioned, it is concluded that there was a prevalence of women of childbearing age, single, brown skin color, undergoing drug therapy, without active sex life, multiple partners, early coitarche and with children. There was high adherence to the CCST and low adherence to family planning, breast examination and STI prevention. Association tests revealed that neither drug treatment nor self-reported diagnosis interferes with women's sexual lives. Nevertheless, the vast majority do not have an active sex life, which opens the way for new research to seek the understanding of the causes that interfere in the non-experience of this dimension of the life of these women.

The results of this study will contribute to improving the quality and access to assistance towards women bearing MD who use local, regional and State and national psychosocial care networks, as well as intending to align the National Policy for Women's Health Comprehensive Care with NMHP, promoting real health integrality. This knowledge is useful for health planning, in addition to providing subsidies to researchers and health professionals in the construction of longitudinal care strategies.

\section{REFERENCES}

1. Brasil. Ministério da Saúde. Política Nacional de Atenção Integral à Saúde da Mulher. Brasília (DF): Ministério da Saúde; 2004. Available at http://bvsms.saude.gov.br/bvs/publicacoes/politica_nac_atencao_ mulher.pdf.

2. Brasil. Ministério da Saúde . Protocolo Clínico e Diretrizes Terapêuticas para Profilaxia Pós- Exposição (PEP) de risco à Infecção pelo HIV, IST e Hepatites Virais. Brasília (DF): Ministério da Saúde 2018. Available at http://www.aids.gov.br/pt-br/pub/2015/protocoloclinico-e-diretrizes-terapeuticas-para-profilaxia-pos-exposicao-pepde-risco.

3. Brasil. Ministério da Saúde. Secretaria de Atenção à Saúde. Saúde Mental no SUS: acesso ao tratamento e mudança do modelo de atenção. Relatório de Gestão 2003-2006. Brasília (DF): Ministério da Saúde; 2007. Available at http://bvsms.saude.gov.br/bvs/publicacoes/ relatorio_gestao_saude_mental_2003-2006.pdf.

4. Pereira MO, Souza JM, Costa AM, Vargas D, Oliveira MAF, Moura, WN. Perfil dos usuários de serviços de Saúde Mental do município de Lorena - São Paulo. Acta Paul Enferm. 2012 jan; 25(1):4854. Available at http://www.scielo.br/scielo.php?pid=S010321002012000100009\&script $=$ sci_abstract\&tlng=pt.

5. Mental health action plan 2013-2020. World Health Organization. Geneva, Switzerland: WHO Document Production Services; 2013, p.8. Available at http://www.who.int/mental_health/publications/ action_plan/en/.

6. Moura ERF, Guedes TG, Freire AS, Bessa AT, Braga VA, Silva RM. Planejamento familiar de mulheres com transtorno mental: o que profissionais do CAPS têm a dizer. Rev Esc Enferm USP 2012, ago; 46(4):935-43. Available at http://www.scielo.br/scielo.php?script=sci arttext\&pid=S0080-62342012000400022.

7. Veloso TMC, Souza MCBM. Concepções de profissionais da estratégia saúde da família sobre saúde mental. Rev. Gaúcha Enferm. [online]. 2013, 34(1):79-85. Available at http://www.scielo.br/scielo. php?script=sci_arttext\&pid=S1983-14472013000100010.
8. Botti NCL, Ferreira SC, Nascimento RG, Pinto ZAF. Condições de Saúde de Mulheres com Transtorno Mental. Rev Rene. 2013; 14(6):1209-16. Available at http://www.redalyc.org/html/3240/324029419018/

9. Brasil. Ministério da Saúde . Portaria $n^{\circ} 336$, de 19 de fevereiro de 2002. Estabelece diretrizes para o funcionamento dos Centros de Atenção Psicossocial. Brasília, DF: Ministério da Saúde; 2002. Available at http://bvsms.saude.gov.br/bvs/saudelegis/gm/2002/ prt0336_19_02_2002.html.

10. Rezende FJF, Montenegro CAB. Rezende: obstetrícia fundamental. 13. ed. Rio de Janeiro: Guanabara Koogan; 2014.

11. Soares AC, Trindade L, Silva R, Gabriela C; Silva FPA, Sai EF. Análise clínica-epidemiológica de pacientes portadores de transtorno mental na amazônia brasileira. Rev Bras Neurol. e Psiq. 2015 maio/ ago;19(2):96-107. Available at https://rbnp.emnuvens.com.br/rbnp/ article/view/55.

12. Kassada DS, Waidman MAP, Miasso AI, Morcon SS. Prevalência de transtornos mentais e fatores associados em gestantes. Acta Paul Enferm. 2015; 28(6):495-502. Available at http://www.scielo.br/scielo. php?pid=S0103-21002015000600495\&script=sci_abstract\&tlng=pt.

13. Mascarello KC, Zandonade E, Amorim MHC. Análise da sobrevida de mulheres com câncer do colo do útero atendidas em hospital de referência para oncologia no Espírito Santo, Brasil, nos anos de 2000 a 2005. Cad Saúde Pública. 2013;29(4):823-31. Available at http://www. scielo.br/scielo.php?pid=S0102-311X2013000400019\&script $=$ sci abstract\&tlng=pt.

14. Barbosa BVF, Cavalcanti A, Alcântara MCA, Pedroza RM, Ferreira SHV. O papel da atenção primária de saúde na constituição das redes de cuidado em saúde mental. Rev Fund Care Online. 2017 jul/ set; 9(3):659-68. Available at http://www.seer.unirio.br/index.php/ cuidadofundamental/article/view/5523.

15. Eduardo KGT, Moura ERF, Nogueira PSF, Costa CBJS, Pinheiro AKB, Silva RM. Conhecimento e mudanças de comportamento de mulheres junto a fatores de risco para câncer de colo uterino. Rev Rene. 2012;13(5):1045-55.

16. Brasil. Ministério da Saúde. Controle dos Cânceres do Colo do Útero e da Mama. Brasília (DF): Ministério da Saúde; 2013. Available at http://bvsms.saude.gov.br/bvs/publicacoes/controle_canceres_colo_ utero_2013.pdf.

17. Lucchese R, Sousa K, Bonfin SP, Vera I, Santana FR. Prevalência de transtorno mental comum na atenção primária. Acta paul. enferm. 2014 jun; 27(3): 200-7. Available at http://www.scielo.br/scielo. php?pid=S0103-21002014000300200\&script=sci_abstract\&tlng=pt.

18. Brasil. Ministério da Saúde. Portaria no 3.088 de 23 de dezembro de 2011.Institui a Rede de Atenção Psicossocial para pessoas com sofrimento ou transtorno mental e com necessidades decorrentes do uso de crack, álcool e outras drogas, no âmbito do Sistema Único de Saúde (SUS). Diário Oficial da União. 25 maio 2013. Available at http:// bvsms.saude.gov.br/bvs/saudelegis/gm/2011/prt3088_23_12_2011_ rep.html.

19. Fisher J, Cabral de Mello M, Patel V, Rahman A, Tran T, Holton SS et al. Prevalence and determinants of common perinatal mental disorders in women in low-and lower-middle-income countries: a systematic review. Bull World Health Organ. 2012; 90(2):139-49. Available at https://www.ncbi.nlm.nih.gov/pmc/articles/PMC3302553/

20. Brasil. Ministério da Saúde. Protocolos da Atenção Básica: Saúde das Mulheres / Ministério da Saúde, Instituto Sírio-Libanês de Ensino e Pesquisa, Brasília: Ministério da Saúde, 2016. Available at http://189.28.128.100/dab/docs/portaldab/publicacoes/protocolo_ saude_mulher.pdf.

21. World Health Organization. Recommendations on antenatal care for a positive pregnancy experience. World Health Organization. Luxembourg: WHO Press; 2016. Available at http://www.who.int/ reproductivehealth/publications/maternal_perinatal_health/ancpositive-pregnancy-experience/en/

22. Teixeira RA, Valente JG, França EB. Mortalidade por câncer de colo do útero no Estado de Minas Gerais, Brasil, 2004-2006: análise da magnitude e diferenciais regionais de óbitos corrigidos. Epidemiol. Serv. Saúde. 2012; 21 (4):549-59.

23. Manfredini V, Calil LN, Backes LTH. Guia Prático de Citologia Cervicovaginal: texto e atlas. São Paulo, SP: Livrobits;2013. Available at http://scielo.iec.gov.br/scielo.php?script=sci arttext\&pid=S1679-49742012000400004. 
24. Torrézio MC, Botti NC. Episódios de cuidados para mulheres com transtornos mentais na atenção primária. Revista Cubana de Enfermería [revista online]. 2017 [citado em 2017, 19 de outubro]; 33 (2): Available at: http://www.revenfermeria.sld.cu/index.php/enf/ article/view/998.

25. Detomini VC, Rasera EF, Peres RS. Sexualidade e Saúde Mental: vivências, serviços e estigmas. Revista da SPAGESP. 2016; 17(2): 81-95. Available at: http://pepsic.bvsalud.org/pdf/rspagesp/v17n2/v17n2a07.pdf.

26. Instituto Nacional de Câncer (BR). Estimativa 2014: incidência de câncer no Brasil/ Instituto Nacional de Câncer José Alencar Gomes da Silva, Coordenação de Prevenção e Vigilância. Rio de Janeiro: INCA, 2014. Available at http://189.28.128.100/dab/docs/portaldab/ publicacoes/protocolo_saude_mulher.pdf.

27. Santiago FS. Acesso aos exames periódicos de saúde entre as mulheres brasileiras acima de 24 anos. Rev Bras Est Reg Urb. 2012 6(2):48-65, 2012.

28. Maluf SW, Tornquist CS. Gênero, saúde e aflição: abordagens antropológicas. Florianópolis, Santa Catarina: Letras Contemporâneas, 2010. Available at: http://transes.paginas.ufsc.br/files/2014/10/ GENEROSAUDEAFLICAO_livro.pdf.

29. Rodrigues, TCGF, Brum IV, Santos JLCT, Juste A, Laporte EGJ Laporte BEP. Conhecimento de 820 mulheres atendidas no Hospital Universitário da Universidade Federal de Juiz de Fora sobre autoexame das mamas. Rev Bras de Mastologia. 2016;26(2):60-4. Available at: http://www.mastology.org/wp-content/uploads/2016/04/MASv26n2.pdf.

30. Brasil. Ministério da Saúde. Controle do câncer de mama: documento de consenso. Rio de Janeiro (RJ): Ministério da Saúde; 2015. Available at http://www.inca.gov.br/publicacoes/Consensointegra.pdf.

Received in: 06/06/2018

Required revisions: 25/02/2019

Approved in: 18/05/2019

Published in: 01/07/2020

\section{Corresponding author}

Valquiria Farias Bezerra Barbosa

Address: Instituto Federal de Educação Ciência e Tecnologia de Pernambuco, Campus Pesqueira

BR 232, Km 208, Portal

Pesqueira/PE, Brazil

Zip code: $55200-000$

Email address: valquiria@pesqueira.ifpe.edu.br 